\title{
PENDEKATAN DAN METODOLOGI PENGAJARAN BAHASA ARAB
}

\author{
Alam Budi Kusuma \\ Sekolah Tinggi Agama Islam Masjid Syuhada \\ Alambudi.kusuma@yahoo.com
}

\section{Abstrak}

Upaya yang dapat dilakukan untuk memahami dan menguasai bahasa Arab diperlukan pengetahuan tentang ilmu yang berkaitan dengan bahasa Arab itu sendiri seperti metode, tata bahasa atau dalam bahasa Arab dikenal dengan Qawaid yang membahas masalah kaidah kaidah dalam bahasa Arab. Secara umum teori belajar bahasa adalah dapat dibagi menjadi struktural, generatif transformatif, behaviorisme dan kognitifisme, Sedangkan metode pengajaran kaidah bahasa arab dapat dibagi menjadi metode gramatikal (grammer method), metode terjemahan (grammar transation), metode langsung (direct method) dan lain-lain, sedangkan metode khusus adalah metode deduktif (al-țariqah al-qiyasiyah), metode induktif (al-țariqah al-istiqraiyyah), metode modifikasi (al-țariqah al-muaddalah), metode keaktifan individu (al-țariqah al-nasyaath al-fardiyah) dan metode prablem solving (al-țariqah al-musykilaat) dari teori teori tersebut dilengkapi dengan teknik masing-masing dalam oprasionalnya.

Kata Kunci : Pendekatan, Metode Pengajaran Bahasa Arab

\section{Abstract}

Efforts that can be made to understand and master the Arabic language required knowledge of science related to the Arabic language itself such as language, language and Arabic language known as Qawaid which discusses the problem of rules of rules in Arabic. In general the theory of language learning can be divided into structural, generative transformative, behaviorism and 
cognitiveism. The method of teaching Arabic language rules can be divided into grammatical methods (grammar methods), translation methods (grammar transation), direct method and others, while the special method is deductive method (al-qariqah al-qiyasiyah), inductive method (al-qariqah al-istiqraiyyah), modification methods (al-qariqah al-muaddalah), the method of individual activism (alqariqah al-nasyaath al-fardiyah) and the prablem solving method (altariqah al-musykilaat) of the theores equipped with each technique in oprasional.

Key words: Approach, Arabic Teaching Methodes

\section{A. PENDAHULUAN}

Masyarakat Indonesia secara sosio-linguistik tidak saja menggunakan satu bahasa di dalam pergaulannya melainkan paling sedikit dua bahasa yakni bahasa ibu dan bahasa nasional. Dengan perkembangan kebudayaan dan peradaban modern, bahasa yang secara umum berfungsi sebagai alat komunikasi dalam kehidupan bermasayarakat ternyata makin menampakkan eksistensinya sebagai media komunikatif efektif, baik dalam perkembangan politik, pendidikan, teknologi, sosial, ekonomi dan agama.

Dewasa ini penguasaan terhadap ragam bahasa tak terkecuali bahasa asing, dirasakan sangat penting. Hal ini disebabkan banyaknya informasi yang dikenal dalam berbagai macam bahasa. Sehingga dengan itu, Indonesia sebagai salah satu negara berkembang dan membenahi diri, semakin sadar akan pentingnya bahasa asing dikuasai oleh masayarakat. Upaya itu telah lama direalisasikan oleh pemerintah, dengan 
adanya kurikulum pendidikan bahasa asing (bahasa Inggris, Arab dan Jerman) di sekolah-sekolah. Baik itu di tingkat menengah pertama, tingkat menengah atas, maupun perguruan tinggi. Bahkan pada lembaga-lembaga non formal, pendidikan bahasa asing telah diterapkan.

Bahasa adalah alat komunikasi, begitu pula dengan bahasa Arab. Bahasa Arab adalah kata yang disampaikan oleh orang arab untuk menyampaikan tujuan mereka. ${ }^{46}$ Dilihat dari fungsinya bahasa Arab adalah alat komunikasi dan penghubung pergaulan bangsa Arab sehari-hari baik antar individu dengan individu, individu dengan masyarakat, maupan masyarakat dengan bangsa tertentudan mencurahkan suatu perasaan dengan rasa senang, sedih, gembira pada orang lain agar dapat difahami, dimengerti, dan merasakan yang ia alami. ${ }^{47}$

Pengajaran bahasa Arab adalah suatu proses pendidikan yang diarahkan untuk mendorong, membimbing, mengembangkan seerta membina kemampuan bahasa Arab, baik secara aktif maupun pasif serta menumbuhkan sikap positif. Adapun yang dimaksud dengan berbahasa Arab aktif yaitu kemampuan bekomunikasi dengan baik dan benar secara lisan, yaitu dalam berkomunikasi atau berbicara dengan orang

46 Musthofa gholayainii, Ja>mi'u ad-Duru>su al-'Arabiyah, (Kairo: Maktabatu as-Syuru>qi ad-Daulati, 1944), hlm. 3.

${ }^{47}$ H. Tayar Yusuf dan Saiful Anwar, Metodologi Pengajaran Agama dan Bahasa Arab, (Jakarta: Grafindo Persada, 1995), hlm. 187. 
lain maupun secara tertulis seperti membuat karangan dan lain sebagainya, sedangkan kemampuan berbahasa pasif yaitu kemampuan untuk memahami pembicaraan orang lain dan kemampuan memahami isi bacaan.

Bahasa-bahasa lain termasuk bahasa Indonesia, tidak dapat diandalkan dalam memberikan kepastian makna baik yang tersurat maupun makna yang tersirat yang terkandung dalam al-Qur'an, karena al-Qu'an diturunkan dalam bahasa Arab, maka kaidah-kaidah yang diperlukan dalam memahami al-Qur'an maupun kitab-kitab yang berbahasa Arab bersendi atas kaidah-kaidah bahasa Arab, memahami asas-asasnya, uslub-uslubnya dan mengetahui rahasia-rahasia maknanya.

Dengan demikian, sangatlah perlu bagi kita untuk mempelajari kaidah-kaidah bahasa Arab, sebagaimana dalam artikel ini akan menjelaskan mengenai pendekatan dan metode pembelajaran bahasa Arab.

\section{B. PEMBAHASAN}

1. Konsep Dasar Pembelajaran Bahasa Arab

\section{a. Sejarah dan pengertiannya}

Awal mulanya pembelajaran kaidah atau gramatikal sebutan dalam bahasa Indonesia telah berlangsung di dunia barat dalam pengajaran bahasa asing yang disamakan dengan pengajaran bahasa Yunani dan Latin di sekolahsekolah. Pembelajaran ini berfokus pada analisa gramatikal, 
penghafan kosa kata, penterjemahan wacana dan latihan menulis. Pada abad ke-18 dan 19 pembelajaran ini yang semua disebut dengan pembelajaran klasik cenderung dianggap sebagai yang utama dalam mengajarkan bahasa asing kemudian berubah menjadi pembelajaran kaidah dan terjemah, walaupun konsep dan penggunaannya tidak berubah sebagaimana keterangan sebelumnya ini. Memang pada dasarnya pembelajaran kaidah seringkali tidak terlepas dari terjemah sehingga ada metode yang disebut dengan kaidah dan terjemah.

Pembelajaran kaidah bahasa Arab bisa juga disebut dengan pembelajaran struktur bahasa (Tarakib Lughawiyah), karena diantara unsur penting yang harus diajarkan adalah tata bahasa, baik nahwuu maupun sarf. Nahwuu merupakan kaidah-kaidah bahasa yang akhir setelah adanya bahasa. Nahwu sebagai realita kebahasaan merupakan aturanaturan yang mengatur penggunaan bahasa dan juga sebagai alat atau media yang membantu untuk memahami kalimat dan struktur-struktur kalimat. ${ }^{48}$ Sedangkan sarf secara bahasa berarti kembali sedangkan secara terminologi adalah kaidah-kaidah bahasa mengenai bentuk dan keadaan kalimat yang bukan dengan i'rob melainkan dengan bina' ${ }^{\prime}{ }^{49}$

48 M. Abdul Hamid, dkk, Pembelajaran bahasa Arab Pendekatan, Metode, Strategi, Materi, dan Media (Malang: UIn Press, 2008), hal. 64-65.

محمد إدريس جوهري, القواعد الصرفية مباحث حول الكلمات العربية في حال أفرادها(سومنب: الأمين 49 برندون, 1983), صن. 1 
Awal mula lahirnya kaidah-kaidah ini disebabkan adanya berbagai kesalahan dalam penggunaan bahasa. Oleh sebab itu, sesungguhnya nahwuu dan sarf itu dipelajari agar pengguna bahasa mampu menyampaikan ungkapan bahasa dan mampu memahaminya dengan benar dan baik dalam bentuk tulisan maupun lisan. Jadi dalam mempelajarinya siswa tidak cukup dengan menghafal kaidah-kaidah nahwuu kemudian selesai, melainkan siswa harus mampu mengaplikasikan kaidah itu dalam membaca dan menulis teks bahasa Arab. Dengan demikian penguasaan kaidahkaidah nahwuu adalah sebagai sarana berbahasa dan bukan merupakan tujuan akhir dari sebuah pembelajaran mengenai bahasa khususnya bahasa Arab.

\section{b. Teori-teori Tata Bahasa}

Dalam linguistik modern terdapat beberapa teori tata bahasa yang perlu dijelaskan karena memiliki keterkaitan dan pengaruh yang cukup signifikan terhadap pembelajaran struktur bahasa, diantaranya:

\section{1) Teori Bahasa Tradisional}

Teori tata bahasa tradisional ini adalah sekumpulan penjelasan dan aturan gramatik dalam linguistic sering dipertentangkan dengan istilah structural. Tata bahasa tradisional menganalisis bahasa berdasarkan filsafat dan semantic, sedangkan tata bahasa structural menganalisis bahasa berdasarkan struktur dan 
cirri-ciri formal yang ada Dalam bahasa. Dalam merumuskan kata kerja misalnya tata bahasa tradisional mengatakan kata kerja adalah kata yang menyatakan tindakan atau kejadian, sedangkan tata bahasa struktural menyatakan kata kerja adalah kata yang berdistribusi dengan frase" dengan". Teori ini membagi kata ke dalam nomina Ism, verbal Fi'il, dan partikel huruf. Teori ini jika diperhatikan sepertinya merupakan teori pertama yang ada dalam tata bahasa, kajiannya pun masih masih bersifat dasar-dasar dari ketatabahasaan, jika kita memperhatikan berbagai literatur buku tentang gramatikal klasik maupun modern sekarang ini kebanyakan mengikuti teori ini.

\section{2) Teori Unsur Bawahan Langsung}

Seiring perkembangan waktu, maka teori ini melihat bahwa kalimat terdiri dari dua unsur bawahan. Setiap unsur bawahan dari kalimat ini juga tersusun dari dua unsur bawahan lagi, dan begitu seteusnya hingga pada kata tunggal. Hal yang tampak jika kita memperhatikan kalimat التلميذ كريم أخلاقه kita bisa mengurainya menjadi dua unsur bawahan كريم أخلاقه + التلميذ, kata jika kita urai juga mempunyai dua unsur أخلاقه demikian juga dengan kata التبلميذ dakahan yakni أخلاق+ yang apabila kita urai terdiri dari 
Implementasi yang dapat diterapkan dari teori ini bahwa guru bisa memanfaatkan dan menerapkan dalam menganalisa kalimat mengganti unsur-unsurnya. Karena mungkin sekali guru memberi model drill latihan pada siswanya dengan cara mengganti dua kata dengan satu kata pada kalimat yang sama.

\section{3) Teori Tagmemik}

Dalam teori ini melihat bahwa kata bisa diklasifikasikan dengan dua cara, yakni morfologi dan sintaksis fungsional. Selain daripada itu, teori ini memperkenalkan jenis-jenis tata bahasa berdasarkan pola kalimat yang sudah ada. Misalnya suatu kata dapat dikategorikan sebagai nomina ism jika bisa mengisi tempat kosong dalam kalimat siatu kata bisa disebut sebagai fi'il jika bisa mengisi tempat kosong pada kalimat beikut suatu kata disebut sebagai partikel harf jika kata itu bukan nomina dan bukan verbal. Sedangkan implementasi teori ini memberikan jasa yang sangat luar biasa dalam latihan pola kalimat patern practice. Pada hakikatnya latihan bahasa sangat memelukan banyak pengulangan. Dengan demikian, kita bisa mengulang-ulang sebuah pola kalimat dengan mengubah beberapa bagiannya. Contoh kalimat أستاذ ماهر, kita bisa mengulang-ulang pola tersebut dengan mengubah kata أستاذmisalnya dengan kata-kata lain yang 
sesuai seperti معلّم, طالب, ولد, طبيبdan sebagainya, sehingga siswa dapat membuat beberapa kalimat yang berbeda dengan satu pola yang sama.

\section{4) Teori Tata Bahasa Transformatif}

Berdasarkan sejarah teori ini merupakan relatif baru yang muncul pertama kali di Amerika sekitar tahun 1950-an. Teori tata bahasa transformatif sendiri memiliki beberapa landasan pemikiran. Menurut teori ini, setiap kalimat memiliki struktur luar dan struktur dalam. Struktur dalam bisa berubah menjadi struktur luar melalui aturan transformasi. Ada yang besifat ijbari dan ada yang besifat $i k h t i b a r i$.

Adapun kelebihan teori ini adalah sisi kejelasannya dan jauh dari samar, karena teori ini meletakkan setiap langkah perubahan subtitusi berdasarkan aturan tertentu. Teori ini mengikuti cara ilmiah dalam perumusan, menyingkat, penomoran dan pembentukan kata.

Implementasi teori ini dalam pembelajaran bahasa Arab memberikan landasan teoritis dalam latihan mengubah, misalnya kalimat positif menjadi kalimat negatif, kalimat tanya menjadi kalimat berita dan sebaliknya, dan kalimat nomina jumlah ismiyah menjadi kalimat verbal jumlah fi'liyah atau sebaliknya. 


\section{Metode Pengajaran dalam Tata Bahasa}

Kata "metode" berasal dari perkataan Yunani yaitu methodos yang berarti 'jalan'...atau 'cara me...sesuatu'. Harimurti Kridalaksana memberikan batasan bahwa suatu metode adalah cara mendekati, mengamati, menganalisa, dan menjelaskan suatu fenomena. ${ }^{50}$ Secara paedagogis, metode adalah cara untuk sampai kepada sesuatu tujuan ${ }^{51}$ Dalam arti yang luas metode adalah cara bertindak menurut sistem aturan tertentu, supaya kegiatan dapat terlaksana dengan praktis dan rasional serta terarah untuk mencapai hasil yang optimal. ${ }^{52}$

Menurut Winarno Surakhmad metode adalah cara yang sebaik-baiknya untuk mencapai suatu tujuan. Hal ini berlaku bagi dunia pendidikan dan pengajaran. Semakin baik metode itu akan semakin efektif pula pencapaian tujuan, dengan memiliki pengertian secara umum mengenai kelemahankelemahannya, seseorang akan lebih mudah memilih dan menetapkan metode yang sesuai dengan situasi dan kondisi yang dihadapi. ${ }^{53}$

Metode dalam pembelajaran bahasa Arab sangat bervariasi, sebagian metode menekankan pada pengajaran kemahiran berbahasa dan sebagian yang lain menekankan

\footnotetext{
50Harimurti Kridalaksana, Kamus Linguistik, Edisi IV (Jakarta: PT. Gramedia Pustaka Utama, 2008), hal.153

51Djaka, Rangkuman Ilmu Mendidik, Jakarta: Mutiara, 1978), hal.24

52Anton Bakker, Metode-Metode Filsafat, Jakarta: Ghalia Indonesia, 1986), hal.10.

53Winarno Surakhmad, Pengantar Interaksi Mengajar-Belajar, Bandung: Tarsito, 1990), hal.23.
} 
pada pengajaran materi bahasa. Sehingga dalam pemberian nama suatu metode pun berdasarkan penekanan-penekanan tersebut, sebagian nama metode diambil dari kemahiran yang ingin dicapai seperti metode membaca (reading method). Sebagian nama yang lain diambil dari materi yang diajarkan seperti metode gramatika (grammar-method) dan metode fonetik (phonetic method). Nama sebagian yang lainnya diambil dari proses pelaksanaannya seperti metode langsung (direct method) dan metode audio-lingual (audio-lingal method). Secara umum teori belajar bahasa dapat dibagi menjadi:

a. Struktural

Perolehan dan perkembangan fonologi dibedakan menjadi dua masa, yaitu masa membabel pra bahasa (prelanguage babbling period) dan masa perolehan bahasa murni (the acquisition of language proper); 2) Keseringan suatu fon dalam bahasa-bahasa di dunialah yang menentukan bahwa fon itu lebih dulu diperoleh, sedangkan bunyi-bunyi yang tidak muncul dalam semua bahasa di dunia akan diperoleh kemudian; 3) Sifat kesejagatan perolehan bahasa mempunyai hubungan yang erat dengan jagat-jagat linguistik.

b. Generatif Transformatif

Bentuk konkret dari teori ini akan terlihat dalam teori belajar bahasa kognitivisme yang akan dijelaskan dalam 
uraian tentang teori belajar bahasa.Di sisi lain, Jack C. Richards dan Thodore S. Rodgers mengemukakan bahwa sekurangnya terdapat tiga pandangan (teori) yang berbeda tentang bahasa yang secara eksplisit ataupun implisit telah mengilhami pendekatan dan metode pengajaran bahasa, yaitu teori struktural, teori fungsional teori interaksional dan tergolong klasik adalah teori struktural yang memandang bahasa sebagai sebuah sistem yang terstruktur, saling berhubungan antara unsur-unsurnya dalam membangun makna. Target pengajaran bahasa menurut teori ini adalah untuk menguasai unsur-unsur dari sistem yang secara umum terdiri dari unsur fonologi, gramatika dan leksikal. Yang kedua adalah teori fungsional yang memandang bahasa sebagai media mengekspresikan makna yang fungsional. Teori ini mengilhami pergerakan komunikatif dalam pengajaran bahasa. Teori ini lebih mengutamakan dimensi semantis dan komunikatif dari pada gramatikal bahasa dan mengarahkan spesifikasi dan organisir materi pengajaran bahasa pada pembahasan-pembahasan yang penuh makna dan fungsional ketimbang unsur-unsur struktur dan gramatika. Ketiga adalah teori interaksional yang memandang bahasa sebagai media untuk merealisasikan dan menginterpretasikan hubunganhubungan dan sebagai sarana komunikasi antar individu. Teori interaksi memusatkan perhatian pada pergerakan- 
pergerakan, aksi-aksi negosiasi dan interaksi sebagaimana yang ditemukan dalam hubungan konvensional. Sehingga materi pengajarannya juga mengarah pada pola-pola ini. Struktural, fungsional dan interaksional merupakan aksioma dan kerangka teoritis yang akan mempengaruhi metode pengajaran

c. Behaviorisme

Teori behaviorisme sebagai teori belajar bahasa dipengaruhi oleh teori bahasa struktural, dan teori ini biasa disebut juga dengan teori mekanistis. Tokoh aliran ini diantaranya adalah Leonard Bloomfield dan Skinner. Aliran behaviorisme dalam bahasa disarikan dari pandangan kaum behavioris tentang conditioning yang menganggap bahwa hewan bisa dilatih untuk melakukan apapun. Untuk melakukan ini, harus mengikuti prosedur yang terdiri dari tiga tahap: stimulus, response, dan reinforcement. Suatu perilaku akan muncul bila didahului oleh stimulus. Perilaku itu dapat diperkuat, dibiasakan, dengan memberi penguatan (reinforcement).

d. Kognitivisme

Kognitivisme dipengaruhi oleh teori bahasa generatif transformasi dan biasa disebut mentalisme yang timbul sebagai reaksi terhadap behaviorisme, teori ini dipelopori oleh linguis Noam Chomsky. Dengan teori ini segera terlihat bahwa linguistik baru itu tidaklah sesuai dengan psikologi 
behaviorisme, baik dari segi alasan-alasan filosofis maupun empiris

Dalam pembelajaran bahasa Arab tidak terlepas dari metode yang digunakan oleh seorang guru, salah satu yang digunakan adalah metode gramatika atau (grammar method) yaitu cara menyajikan materi atau bahan pelajaran dengan jalan menghafal aturan-aturan atau kaidah-kaidah tata bahasa untuk bahasa asing tersebut. Jadi, peserta didik diajarkan terlebih dahulu gramatika atau tata bahasa. ${ }^{54}$

Dasar pokok metode ini adalah hafalan kaidah, analisa gramatika terhadap wacana, lalu terjemahnya kedalam bahasa yang digunakan sebagai pengantar pelajaran. Titik tekan metode ini bukan melatih memahami bahasa secara logis yang didasarkan kepada analisa cermat terhadap aspek kaidah tata bahasa. ${ }^{55}$

Tujuan metode ini adalah agar para peserta didik pandai dalam menghafal dan memahami tata bahasa, mengungkapkan ide-ide dengan menerjemahkan bahasa ibu atau bahasa kedua kedalam bahasa asing yang dipelajari, dan membekali peserta didik agar mampu memahami teks bahasa asing dengan menerjemahkannya kedalam bahasa sehari-hari atau sebaliknya. ${ }^{56}$ 2009), hal. 104

54 Ahmad Izzan, Metode Pembelajaran Bahasa Arab (Bandung: Humaniora, 55 Chaedar Alwasilah, Metode Pembelajaran Bahasa Arab (Bandung: PT Remaja Rosdakarya, 2011), hal. 171

56Ibid, hal 171

100 Jurnal Komunikasi dan Pendidikan Islam, Volume 1, Nomor 1, Juni 2018 
Metode gramatika memiliki beberapa karakter, diantaranya adalah sebagai berikut:

1) Materi pelajaran terdiri dari buku nahwuu, kamus, dan teks bacaan

2) Tata bahasa disajikan secara deduktif, yaitu dimulai dengan penyajian kaidah diikuti dengan contoh-contoh dan dijelaskan secaa rinci dan panjang lebar

3) Kosa kata diberikan dalam bentuk kamus dwibahasa atau daftar kosa kata beserta terjemahannya

4) Basis pembelajaran adalah penghafalan kaidah-kaidah tata bahasa dan kosa kata, kemudian penerjemahan hafiah dari bahasa asing yang dipelajari ke dalam bahasa peserta didik atau sebaliknya

5) Peran aktif guru sebagai penyaji materi, perran peserta didi pasif sebagai penerima materi

6) Bahasa ibu peserta didik digunakan sebagai bahasa pengantar dalam kegiatan belajar mengajar. Bahasa tersebut dipakai untuk menjelaskan sesuatu yang baru kepada peserta didik. ${ }^{57}$

Langkah-langkah yang digunakan guru dalam menyampaikan materi kaidah dengan menggunakan metode ini pada umumnya sebagai berikut:

57 Ahmad Fuad Efendy, Metode Pengajaran Bahasa Arab (Malang: Misyikat, 
1) Pendahuluan, memuat berbagai hal yang berkaitan dengan materi yang akan disajikan baik berupa apersepsi atau tes awal tentang materi atau yang lainnya

2) Guru memberikan pengenalan dan definisi kaidahkaidah tata bahasa Arab yang harus dihafalkan sesuai dengan materi yang akan disajikan berikut terjemahannya dalam bahasa peserta didik

3) Jika terdapat kosa kata yang dipandang sulit untuk diterjemahkan, guru menjelaskan kosa kata tersebut terlebih dahulu

4) Guru memberikan materi teks bahasa Arab, lalu mengajak peserta didik untuk menerjemahkan kata demi kata, kalimat demi kalimat dan paragraf demi paragraf. Setelah itu, peserta didik mencocokan, mengidentifikasi, dan menganalisis kaidah-kaidah yang telah dihafalkan dengan teks baru tersebut

5) Guru memberi daftar kosa kata yang lepas dari konteks kalimat untuk dihafalkan. 58

Pada dasarnya langkah-langkah di atas bukanlah suatu kemestian, sebab pada tingkat selanjutnya metode ini diserahkan kepada guru untuk dikembangkan sesuai dengan situasi dan kondisi yang ada.

Metode gramatika juga memiliki kelebihan dan juga tidak terlepas dai kekurangan karena tidak ada suatu hal. 173-174 
metode yang baik ataupun benar, yang ada adalah metode yang digunakan apakah sesuai dengan tujuannya atau tidak dan sifat dari metode pembelajaran adalah saling melengkapi antara metode yang satu dengan metode yang lainnya. Berikut kelebihan dari metode gramatika:

1) Para peserta didik dapat menghafal kosa kata dalam jumlah yang relatif banyak dalam setiap pertemuan

2) Para peserta didik dapat menghafal kaidah-kaidah bahasa asing yang disampaikan dalam bahasa sehari-hari karena senantiasa menggunakan terjemahan dalam bahasa sehari-hari

3) Metode ini memperkuat kemampuan pelajar dalam mengingat dan menghafal ${ }^{59}$

4) Melatih mental disiplin da ulet dalam mempelajari bahasa $^{60}$

Metode ini dari segi kelemahan adalah sebagai berikut:

1) Secara didaktis dan psikologi metode ini bertentangan dengan kenyataan bahwa pengetahuan bahasa seseorang tidaklah didahului dengan mengajarkan gamatika atau tata bahasa

2) Metode ini lebih banyak mengajarkan tentang bahasa bukan mengajarkan ketrampilan bahasa

${ }^{60}$ Ahmad Izzan, Metode Pembelajaran................, hal. 104 
3) Terjemahan kata perkata sering mengacaukan makna kalimat dalam konteks yang luas

4) Para peserta didik hanya mempelajari satu ragam bahasa, yaitu ragam bahasa tulis klasik. Sedangkan bahasa tulis moden dan bahasa percakapan tidak diperoleh oleh siswa

5) Tidak bertumbuhnya ekspresi dan kreasi berbahasa karena otak siswa dipenuhi oleh kaidah-kaidah tata bahasa. ${ }^{61}$

Dari berbagai pandangan para ahli bahasa Arab, telah disepakati bahwasanya penguasaan kaidah-kaidah nahwuu dan saraf bukan merupakan tujuan pembelajaran bahasa Arab melainkan hanya sebagai sarana untuk membantu para siswa agar mampu berbicara, membaca seta menulis dengan benar, dan sebenarnya masih banyak lagi sarana lainnya yang juga bisa membantu siswa, diantaranya lingkungan bahasa yang baik, pembiasaan berbicara, menulis dan sebagainya. Oleh karena itu, dalam pembelajarannya memiliki beberapa tujuan yaitu:

1) Ketepatan tanda baca nahwuu saraf yang baik agar siswa terlindungi dari kesalahan

2) Menjadikan kebiasaan itu tepat, sehingga untuk mencapai pada kaidah itu diperlukan contoh-contoh, diskusi tentang kaidah baik lisan maupun tulisan sampai siswa memperoleh manfaan bahasa dalam menyusun hal. $42-43$ 
kalimat, ungkapan yang fasih, ekspresi penampilan dan lain sebagainya yang berhubungan dengan hal tersebut

3) Pemahaman format dan umus bahasa, sehingga memahami perbedaan struktur bahasa seperti Istifham, nafi, taukud, ta'ajub, istitsna dan lain sebagainya $\backslash$.

4) Pertumbuhan rasa sastra yaitu dengan metode ekspresi sastra yang tepat dan sesuai dengan kaidah nahwuu yang baru

Dari penjelasan di atas bahwa nahwuu itu tergantung pada analisa, pertimbangan, kesimpulan, penentuan dan identifikasi kebenaran atas kesalahan pada ekspesi yang berbeda-beda. Serta pemahaman struktur yang samar dan kompleks, latihan keakuratan pemikiran, silogisme, kemampuan berfikir dan keakuratan perhatian. ${ }^{62}$

Selanjutnya metode terjemahan gramatika (grammartranslation method) Metode terjemahan gramatika dimulai dengan pengajaran kaidah-kaidah gramatika dan daftardaftar kosa kata dwi-bahasa yang berkaitan erat dengan bahan bacaan pada pelajaran yang bersangkutan. Gramatika dibelajarkan secara deduktif dengan penjelasan-penjelasan yang panjang dan terperinci. Sedangkan dalam metode langsung, kaidah gramatika tidak diajarkan secara eksplisit, kaidah-kaidah tersebut diharapkan dapat dipelajari melalui praktek dan latihan, kemudian anak didik didorong untuk

عبد الفتاح حسن البجة: أصول تدريس العربية بين النظرية و الممارسة, (دار الفكرة, عمان الأردان,1999), 62 
membuat generalisasi-generalisasi tentang kaidah gramatika secara induktif. Kalau kaidah gramatika harus diajarkan secara eksplisit maka harus menggunakan bahan sasaran.

\section{Metode Khusus Pembelajaran Sintaksis atau Qawa'id}

Sedangkan dalam pengembangan metode-metode tersebut digunakan metode-metode yang khusus berhubungan dengan pengajaran nahwuu atau kaidah yang bisa menjadi acuan konkret dalam merumuskan teknik-teknik pembelajaran nahwu. Metode-metode tersebut adalah:

a. al-Tharîqah al-Qiyâsiyyah (metode deduktif)

Metode ini merupakan pioner dalam khazanah metode pengajaran nahwu dan memiliki peran penting dalam sistem pembelajaran klasik. Metode ini disusun berdasarkan pola pikir deduktif, berpikir dari umum ke khusus, dari ma 'lûm ke majhûl, dari ketentuan umum menuju penerapan khusus, dari kulli ke juz'i, dari kaidah menuju contoh. Alqiyâs (analogi) dilakukan setelah mengetahui al-maqîs 'alaih (kaidah) sebagai model imitatif. Langkah-langkah metode ini adalah; 1) Guru menyebutkan kaidah (ta'rîf) atau konsep umum; 2) Guru menjelaskan kaidah dengan menyertakan contoh-contoh; 3) Penerapan kaidah-kaidah dalam contohcontoh yang lebih luas.

Metode ini tergolong gampang dilaksanakan dengan waktu yang relatif singkat sehingga metode ini banyak digunakan dalam pengajaran nahwuu. Tapi metode ini 
membiasakan anak didik menghafal kaidah dan menirukan contoh-contohnya sehingga menyebabkan anak kurang aktif. Sedangkan dari aspek logika pengajarannya, metode ini dimulai dengan kaidah-kaidah umum yang biasanya menyulitkan bagi anak untuk memahaminya, sehingga metode ini menyalahi prinsip pengajaran bahwa pengajaran harus dimulai dengan sesuatu yang mudah menuju yang sulit.

b. al-Tharîgah al-istiqrâiyyah (metode induktif)

Munculnya metode ini dilatarbelakangi oleh lima langkah pengajaran yang dikemukakan oleh filosof Jerman Frederick Herbart (1776-1844), yaitu: appersepsi, penyajian materi, korelasi materi, konklusi dan aplikasi. Metode ini disusun berdasarkan pola pikir induktif, berpikir dari khusus ke umum, dari penerapan-penerapan khusus menuju ketentuan umum, dari contoh kepada konsep. Metode ini membiasakan siswa untuk menarik kesimpulan sendiri. Walaupun membutuhkan waktu pembelajaran yang agak lama, tapi metode ini mendidik anak untuk menganalisa contoh-contoh yang ada sampai menemukan sendiri kaidah-kaidah yang ada di dalamnya. Pengajaran seperti ini relatif lebih berkesan bagi anak didik.

c. al-Tharîgah al-mu'addalah (metode modifikasi)

Metode ini merupakan hasil modifikasi dari dua metode sebelumnya dengan membelajarkan nahwuu 
melalui teks dengan topik-topik yang menarik bagi anak. Dari teks tersebut dipilih kalimat-kalimat yang memiliki karakteristik tertentu kemudian dirumuskan kaidah dan terakhir diaplikasikan.

Dalam metode ini, nahwu yang diajarkan bersifat naturalistik, karena nahwu dibelajarkan melalui bahasa dengan sifat-sifat kealamiahannya yang digunakan di dalam teks. Metode ini memuat dua aspek utama, yaitu tarkîb (struktur) dan dalâlah (semantis) sehingga terlihat urgensi nahwu dalam menemukan makna sebuah teks.

d. At- Tharîqah an-Nasyâth (Metode aktivitas)

Metode ini menuntut banyak aktifitas peserta didik untuk mengumpulkan kalimat dan struktur yang mengandung konsep qawa'id yang hendak dipelajari dari berbagai sumber seperti Koran, majalah, atau buku. Lalu guru mengambil kesimpulan terhadap konsep qawa'id itu, lalu menuliskannya, kemudian diaplikasikan dalam contohcontoh lain.

e. Tharîgahhal-almusykilât (metode problem solving)

Metode ini dilaksanakan atas dasar penyelesaian kesulitan-kesulitan atau masalah-masalah yang ditemui anak didik ketika berbicara ataupun menulis, sehingga pelajaran ta'bîr atau qirâ'ah bisa menjadi langkah awal untuk mendeteksi kesulitan-kesulitan nahwu yang dihadapi anak didik, kemudian guru mengarahkankan perhatian 
anak bahwa kesulitan nahwu tersebut akan menjadi topik bahasan pelajaran nahwu dalam kesempatan berikutnya. Kesulitan-kesulitan nahwu yang dihadapi anak didik juga dapat dideteksi melalui karangan-karangn anak. Kesulitankesulitan tersebut didiskusikan dan kemudian disimpulkan kaidah-kaidah yang terkandung di dalamnya. Metode ini menuntut kecerdasan guru dalam mendeteksi kesalahankesalahan nahwu yang dilakukan anak didik.

\section{KESIMPULAN}

Penerapan metode pembelajaran tidak akan berjalan dengan efektif dan efisien sebagai media pengantar materi pengajaran bila penerapannya tanpa didasari dengan pengetahuan yang memadai tentang metode itu sendiri. Sehingga metode bisa saja akan menjadi penghambat jalannya proses pengajaran, bukan komponen yang menunjang pencapaian tujuan, juga tidak tepat aplikasinya. Oleh karena itu, penting sekali untuk memahami dengan baik dan benar tentang karakteristik suatu metode.

Penguasaan kaidah-kaidah nahwuu dan saraf bukan merupakan tujuan pembelajaran bahasa, melainkan hanya merupakan sebagai sarana untuk membantu siswa agar mampu mengembangkan empat keterampilan berbahasa Arab, yaitu: berbicara, membaca, mendengarkan, serta menulis. 


\section{DAFTAR PUSTAKA}

Alwasilah, Chaedar. 2011. Metode Pembelajaran Bahasa Arab. Bandung: PT Remaja Rosdakarya.

Efendy, Ahmad Fuad. 2009. Metode Pengajaran Bahasa Arab. Malang: Misyikat.

Gholayainii, Musthofa. 1994. Ja $>$ mi'u ad-Duru $>$ su al-'Arabiyah, (Kairo: Maktabatu as-Syuru>qi ad-Daulati.

Hamid, M. Abdul dkk. 2008. Pembelajaran bahasa Arab Pendekatan, Metode, Strategi, Materi, dan Media. Malang: UIN Press.

Izzan,Ahmad. 2009. Metode Pembelajaran Bahasa Arab. Bandung: Humaniora

Yusuf, Tayar dan Saiful Anwar. 1995. Metodologi Pengajaran Agama dan Bahasa Arab. Jakarta: Grafindo Persada.

عبد الفتاح حسن البجة. 1999. أصول تدريس العربية بين النظرية و الممارسة دار الفكرة, عمان الأردان.

محمد إدريس جوهري, 1983. القو اعد الصرفية مباحث حول الكلمات العربية

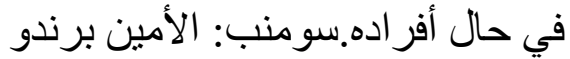

